\title{
4.0 Indonesian Pre-service Teachers; are they ready for 4Cs? A case study
}

\author{
Fransisca Endang Lestariningsih \\ (endang@staff.ukdw.ac.id) \\ English Language Education Department \\ Duta Wacana Christian University, \\ Jl. Dr. Wahidin Sudirohusodo No.5-25, Kotabaru, Kec. Gondokusuman, Kota Yogyakarta, Daerah \\ Istimewa Yogyakarta 55224 Indonesia
}

\begin{abstract}
Highly qualified and competent teachers are the key to excellent education systems. Therefore in this 21 st century industrial era 4.0, an education department, which prepares its students to be able to effectively teach and fruitfully educate their future students in the borderless information technology, does not merely need to meet the needs of industry, but also to ensure the best potential student experience. This paper is a report of observation and self-reflection of eleven pre-service teachers on whether or not they were ready to apply one of the 4Cs (critical thinking, creativity, collaboration, and communication) in the $21^{\text {st }}$-century education. The emphasis of the study was the third $\mathrm{C}$, collaboration. The result of this study depicts that even though they preferred to work in groups, mostly, they were not yet ready to work together with their peers to achieve a certain goal.
\end{abstract}

Keywords: pre-service teachers, industrial era 4.0, $21^{\text {st }}$-century education, collaboration

\section{Introduction}

"Highly qualified and competent teachers are the key for excellent education systems" [1]. The statement was repetitively disseminated by the Organization for Economic Co-operation and Development (OECD). In achieving what OECD has stated in the 21 st century education, a pre-service teacher training department has a responsibility to prepare its students to be able to think critically, be creative, collaborate, and communicate effectively and efficiently. Miri, David and Uri acknowledged that in the ever-changing and challenging (disruptive) world, students, as future citizens, are demanded to be able to see beyond their school of capacity [2]. They furthermore argued that students need to develop their higher-order thinking skills (HOTS) such as critical thinking, decision making, and problem-solving.

It is crucial to rethinking pedagogy for the $21^{\text {st }}$ century as well as identifying the new competencies that today's learners need to develop [3]. The 4Cs principle - critical thinking, communication, collaboration, and creativity - alongside 'teaching for transfer', learning structured in real-world contexts. Motivation and problem-solving are what andragogy is all about. Scott (2005) therefore, argues that in facing a difficult, uncertain and complex future, one of the ways to be transferred to students is through problem-based learning. Therefore it is 
necessary to discuss what higher-order thinking (HOT) skills are since problem-based learning needs such a kind of thinking. The skills of HOT outweigh the counterpart, low-order thinking (LOT) skills. HOT skills are divided into three categories, HOT as transfer, HOT as critical thinking, and HOT as problem-solving [4].

Anderson and Krathwohl's division of HOT is some of the most well-known approaches of HOT [4]. They divide learning into learning for recall and learning for transfer. Even though learning for recall surely needs a type of thinking, it is learning for transfer that they believe as meaningful learning, which the writer also believes that transferable skills should be possessed by learners to learn other skills. As critical thinking, HOT requires learners to be able to think that makes them able to apply wise judgment or produce a reasoned critique [4]. HOT as problem-solving is equipping students "to be able to identify and solve problems in their academic work and life." (p. 8).

Concerning the skills of solving problems in academic life, this paper is a report of the writer's observation of ten pre-service English teachers of a private university in Yogyakarta, Indonesia combined with their self-reflections on their problems in group working. The issue was raised due to the class dynamic showing that the students found difficulties in dealing with working in groups or collaborating with their friends in reaching a certain goal. Such challenges were quite a cliche, such as how to deal with ignorant students who did not participate actively in the group work and reaching the same decision in the group.

\section{Method}

This study was a mix between quantitative study and qualitative study. An observation and reflection writing were the techniques applied to gather the data. The observation included students 'perceptions before, during and after the collaboration works were assigned to the students. During the process of collaborating, the researcher conducted some discussions to find any problems arisen among them. Students 'final grade was used as a comparison to see whether collaboration influenced the academic achievements of the students. The participants of this study were eleven students of semester five of an undergraduate program at a private university in Yogyakata, Indonesia, who took a subject called English for Specific Purposes (ESP) Program Design.

\section{Result and Discussion}

\subsection{Class Dynamic}

The objective of the ESP Program Design class was to prepare the students to design a course program of ESP. ESP refers to the teaching and learning of English either as a second or foreign language in which the goal of the learners is to use English in a particular domain where the language can be considered as a tool for communication rather than as sets of phonological, grammatical and lexical items [5] [6]. ESP was an important subcomponent of language teaching with its approaches to curriculum development, materials design, pedagogy, testing and research [6]. Since the goal of ESP is that the learners can use English in a particular domain, analyzing the needs of the learner becomes the must and the beginning of designing the materials for any ESP program. Thus, those ten students taking ESP Program Design class needed some prior information before they could design their course. 
Due to that purpose, the writer grouped the students, which became the population of this study, into three groups of three and one group of two. These groups not only worked for the needs analysis purposes but also turned out to be what they called everlasting groups, in which they would work together during the process of designing the ESP course. The groups were randomly made, which did not give any possibility of the students to pick other students based on their preferences. This way of grouping technique was chosen with the assumption that the students were mature enough to be able to deal with others. Another assumption to put them in random groups was the trend of the $21^{\text {st }}$-century education, which would train them to be able to work collaboratively. Duke university even concludes that "Greater collaboration, greater security, and technology-driven education - that is how the future of education looks like" [7]. The collaboration deals with sharing knowledge and working together as a team to reach the same goal.

Problems appeared since the very beginning of forming the groups. There were already gaps among the students. Some very active students did not want to work with the non-active ones. Unfortunately, the non-active students' academic achievement was below the average, while the active ones were quite good at their academic achievement. With the assumption that the students were quite mature so that they could deal with the unpredictable situation (one phenomenon in the 21 st century - disruptive world), the grouping was set randomly. Another reason why they were not grouped with whomever they wanted was to avoid jealousy and ill-feeling among them.

The result of the grouping was noteworthy because the composition of the groups was some active and not-active students. Up to this process, the teacher, as the researcher, was quite worried with the dynamic in the groups since the background of the students showed that some students were unwanted. This concern emerged because they looked upset with the result of the grouping.

\subsection{Problem-solving Discussion}

The students in the studied class were parts of industry 4.0, which refers to the concept in which connectivity is unlimited and unbounded. This phenomenon bursts the emergence of individual work, as what was acknowledged by the Duke Perspective as follows

When the professor measures the student's performance and behavior, they can finally offer a personalized learning experience for them. If an individual student is facing learning disabilities, they can find a different approach in their teaching methods. [7]

In this industry 4.0, each student has the bigger opportunity to solve their problems in learning so that the chances to ask their peers or others for help is low. Thus the challenge in education is how the students can collaborate to reach the same goal. One of the characteristics of collaborative work is to motivate the workforce and create a healthy environment [8]. This situation did not exist in the class due to the objections of some students to work with certain students. Some techniques were used to overcome the problems with some assumptions.

One method used was face-to-face discussion. The purpose of doing this method was to foster a paradigm shift - an important change that happens when the usual way of thinking about or doing something is replaced by a new and different way [9]. The teacher invited three students, one by one, who potentially had difficulties in working in groups. The students were from three separate groups. The focus of the discussion was whether or not they found challenges in team working. One weak student revealed that he did not know how to see himself, and he realized he could not communicate with his team, as he said (written verbatim) 
"I just know that I often act weird in the point of view of some people. I realize that not everybody can accept my behavior. I also realized that I often ignore the task immediately and cannot communicate with them. What can I do is trying to be proactive."

An active student from different group said that

"I've done my best to work together with student X. Honestly I did not have a laptop because it was broken, but I often be responsible to work on the assignment with that student. Sadly, I am not a patient person, but I am trying to be more patient, and hope that my partner could be more responsible."

The last student, in the face-to-face discussion, was the most diligent in the class. She said that she did not like people who work slowly. That was the reason why she found it difficult to work with her partner, who always had reasons not to come to the agreed schedule, and never did the assigned job. What she could do to overcome the problem was to always remind her partner to be responsible and to avoid becoming a procrastinator.

The result of the face-to-face discussion gave the impression that the students who faced difficulty in working with their peers would find ways to overcome the problems for they could finish their class project. The final score of the students, as shown in Table 1, also supported that as if the class dynamic was good. This result, however, was slightly different from the findings of reflections after the class ended.

Table 1. Students' Final Grade

\begin{tabular}{ccc}
\hline No & Name & Grade \\
\hline 1 & Student A & B+ \\
2 & Student B & A- \\
3 & Student C & B+ \\
4 & Student D & A- \\
5 & Student E & A- \\
6 & Student F & A- \\
7 & Student G & A- \\
8 & Student H & B \\
9 & Student I & A \\
10 & Student J & A \\
11 & Student K & B+ \\
\hline
\end{tabular}

\subsection{Post-Group-Work Reflections}

The class dynamic and the final grade result depicted that the group work ran quite smoothly. Nevertheless, the result of the students' reflections was slightly different. The following table (Table 2) was the reflection of four students when they were asked the 
following questions: 1) were you happy to work in groups? Why? and 2) If you may choose, do you prefer to work in groups or individually?; while Table 3 is the positive or negative attitude of experiencing group work and their preference for working in groups to working individually.

Table 2. Students' Reflection

\begin{tabular}{|c|c|c|}
\hline Student & $\begin{array}{l}\text { Were you happy to work in groups? Why? } \\
\text { (Question 1) }\end{array}$ & $\begin{array}{c}\text { If you may choose, do you prefer to work in groups or } \\
\text { individually? (Question 2) }\end{array}$ \\
\hline Student A & $\begin{array}{l}\text { I was not really happy in ESPPD class as I have } \\
\text { to work in a group and it was challenging. } \\
\text { Working in a group was not easy at all, as we } \\
\text { have a different point of view, characteristics, and } \\
\text { time management. I had to be patient when the } \\
\text { members could not do their parts well, I had to be } \\
\text { proactive, and of course, gave my best effort for } \\
\text { the project. }\end{array}$ & $\begin{array}{l}\text { Although group work was really challenging, I prefer to } \\
\text { work in groups because it trains me about how to work } \\
\text { with other people who have different opinions, } \\
\text { characteristics, and time management because in the real } \\
\text { job, I will meet new people with various backgrounds. } \\
\text { Through group work, I learn not only about the project but I } \\
\text { also learn about working in a team. }\end{array}$ \\
\hline Student $\mathbf{H}$ & $\begin{array}{l}\text { I feel just so-so because I already work in a group } \\
\text { for a hundred times. }\end{array}$ & $\begin{array}{l}\text { It depends on the members. I'd love to work in the group } \\
\text { if they want to work hard together and they are supportive } \\
\text { I'd love to. }\end{array}$ \\
\hline Student F & $\begin{array}{l}\text { I was quite happy. Because my member could } \\
\text { handle the design of the materials. }\end{array}$ & $\begin{array}{l}\text { I prefer to work individually so I can handle everything on } \\
\text { my own }\end{array}$ \\
\hline Student D & $\begin{array}{l}\text { Yes, because teamwork can help us to improve } \\
\text { communication skills and increase collaboration } \\
\text { skills }\end{array}$ & $\begin{array}{l}\text { But sometimes I prefer to work in group because it helps } \\
\text { me to combine some ideas into the assignment }\end{array}$ \\
\hline
\end{tabular}

Table 3. Students' Attitude

\begin{tabular}{rll}
\hline Student & \multicolumn{1}{c}{ Group work experience } & \multicolumn{1}{c}{ Preference } \\
\hline Student A & Negative & Group Work \\
Student H & Almost negative & Group Work with conditions \\
Student F & Almost positive & Individual Work \\
Student D & Positive & Group Work \\
\hline
\end{tabular}

The above findings (Table 2 and Table 3), to some extent, raise confusion since there is no correlation between students' preference in working in groups to their experiences. On the one hand, Student A liked to work in a group but experienced negative teamwork. Student C, on the other hand, preferred to work individually, but she found out that working with her partner could help her finish the task. 


\section{Conclusion}

Collaboration is one of the characteristics of 21 st-century education, where industrial era 4.0 requires young generations to be ready with uncertainty. Pre-service teachers are part of this era. Thus a department that prepares its students to be teachers has a responsibility to prepare them to be able to deal with the requirements needed in industrial era 4.0, specifically in collaboration. As a report of an observation and students' self-reflections, this paper found out that some students were fond of working in groups; however, they did not enjoy the process because of reasons such as they found difficulties in managing time and their partners could not do their parts. These findings conclude that this generation does need to train their collaborative skills, as mentioned by the Duke Perspective, that the future of education will emphasize more on greater collaboration, greater security, and technology-driven education [7].

\section{References}

[1] S. Guerriero, Pedagogical Knowledge and the Changing Nature of the Teaching Profession, Paris: OECD Publishing, 2017.

[2] M. Barak, D. Ben-Chaim dan Z. Uri, "Purposely Teaching for the Promotion of Higherorder Thinking Skills: A Case of Critical Thinking," Research in Science Education, vol. 37, pp. 353-369, 2007.

[3] C. L. Scott, "The Futures of Learning 3 : what kind of pedagogies for the 21 st century?," Education Research and Foresight Working, 2015.

[4] S. M. Brookhart, How to Assess Higher-Order Thinking Skills in Your Classrooms, Virginia: ASCD, 2010.

[5] B. Paltridge dan S. Starfield, The Handbook of English for Specific Purposes, Oxford: Wiley-Blackwell, 2013.

[6] D. Nunan, Task-Based Language Teaching, Cambridge: Cambridge University Press, 2010.

[7] T. D. Perspective, "The Duke Perspective," [Online]. Available: https://sites.duke.edu/perspective/2019/03/21/impact-of-industry-4-0-on-education/. [Diakses 21 March 2019].

[8] S. Kashyap, "ProofHub," [Online]. Available: https://www.proofhub.com/articles/collaborative-working-environment. [Diakses 3 September 2018].

[9] "Merriam-Webster," [Online]. Available: https://www.merriamwebster.com/dictionary/paradigm\%20shift. 
